\title{
A New Insight into Hepatitis C Vaccine Development
}

\author{
Chun I. Yu and Bor-Luen Chiang \\ Graduate Institute of Clinical Medicine, College of Medicine, National Taiwan University, No. 1 Chang-Te Street, \\ Taipei 100, Taiwan \\ Correspondence should be addressed to Bor-Luen Chiang, gicmbor@ntu.edu.tw
}

Received 14 December 2009; Revised 25 February 2010; Accepted 5 April 2010

Academic Editor: Zhengguo Xiao

Copyright ( $) 2010$ C. I. Yu and B.-L. Chiang. This is an open access article distributed under the Creative Commons Attribution License, which permits unrestricted use, distribution, and reproduction in any medium, provided the original work is properly cited.

\begin{abstract}
Chronic hepatitis $\mathrm{C}$ virus (HCV) infection remains a serious burden to public health worldwide. Currently, HCV-infected patients could undergo antiviral therapy by giving pegylated IFN- $\alpha$ with ribavirin. However, this therapy is only effective in around $50 \%$ of patients with HCV genotype 1, which accounts for more than 70\% of all HCV infection, and it is not well tolerated for most patients. Moreover, there is no vaccine available. The efforts on identifying protective immunity against HCV have progressed recently. Neutralizing antibodies and robust $\mathrm{T}$ cell responses including both $\mathrm{CD} 4^{+}$and $\mathrm{CD} 8^{+}$have been shown to be related to the clearance of HCV, which have shed lights on the potential success of HCV vaccines. There are many vaccines developed and tested before entering clinical trials. Here, we would first discuss strategies of viral immune evasion and correlates of protective host immunity and finally review some prospective vaccine approaches against chronic HCV infection.
\end{abstract}

\section{Introduction}

More than 170 million people are currently affected by chronic hepatitis $\mathrm{C}$ virus (HCV) infection worldwide with the highest prevalence in Africa and Asia [1-3]. Since the adoption of the all volunteer blood donor system to screen blood donations in 1990s, the incidence of HCV infection has dropped dramatically. However, some populations remain highly susceptible including drug users sharing the same devices and patients that have received unsafe therapeutic injection or unsafe blood transfer [4]. Among all HCV infected individuals, $80 \%$ of them remain chronically infected $[4,5], 10 \%-20 \%$ of them develop cirrhosis, and $1 \%-$ $5 \%$ of them acquire liver cancer over years [6]. Therefore, previous incidence as well as new incidence all account for future disease burdens. In developed countries, HCV infection has became the leading cause for the failure of liver transplants [1]. Up until now, there is no vaccine available for HCV infection. HCV-infected patients could receive anti-viral therapy by giving pegylated interferon- $\alpha$ (PEG-IFN) with ribavirin [7]. However, this therapy is long, expensive, toxic, and only effective in around $50 \%$ of patients for the most common genotype [8]. A regimen of 48-week therapy with PEG-IFN and ribavirin costing \$25,000 USD is recommended for HCV genotype 1 and 24-week therapy for HCV genotype 2/3 [9]. There are many side effects associated with PEG-IFN, which have lead to early withdrawals or dose modification, including neutropenia, flulike symptoms, neuropsychiatric disorders like depression, and autoimmune syndromes like autoimmune thyroiditis [8]. A sustained virological response (SVR) representing long lasting disappearance of viral RNA in the serum can be achieved in $80 \%-90 \%$ of genotype $2 / 3$ but only around $40 \%-50 \%$ of genotype $1[10,11]$, which accounts for more than $70 \%$ of HCV infection in US $[12,13]$. Therefore, the development of effective vaccines for $\mathrm{HCV}$, especially therapeutic, is crucial in controlling chronic HCV infection.

$\mathrm{HCV}$ is an RNA virus with enveloped virion belonging to the family Flaviviridae. It contains a positive-sense singlestranded RNA genome that is 9,600 nucleotides in length. HCV genomic RNA is composed of one open-reading frame flanked by $5^{\prime}$ and $3^{\prime}$ noncoding region. The HCV polyprotein encoded by the only open-reading frame is approximately 3,000 amino acids in length and is cleaved into three structure proteins (core, E1, and E2), and seven nonstructural proteins (p7, NS2, NS3, NS4A, NS4B, NS5A, and NS5B) [14]. According to international standardization and coordination of the nomenclature of variants of hepatitis 
TABle 1: HCV genotypes, subtypes, and their geographical distributions.

\begin{tabular}{lcc}
\hline Genotypes & Subtypes & $\begin{array}{c}\text { Geographical } \\
\text { Distribution }\end{array}$ \\
\hline 1 & a, b, c & $\begin{array}{l}\text { Central Africa, } \\
\text { Europe, North } \\
\text { America }\end{array}$ \\
2 & a, b, c, k & Western Africa \\
3 & a, b, k & Southeast Asia \\
4 & a & Central Africa \\
5 & a & \\
6 & a, b, d, g, h, k & Southeast Asia \\
\hline
\end{tabular}

C virus, HCV is classified into 6 clades or genotypes with $31 \%-33 \%$ diversity in nucleotide based on partial sequences of core/E1 and NS5B, or complete sequences. Each genotype is further divided into different subtypes with $20 \%-25 \%$ differences (Table 1) [15]. The importance of HCV genotype lies in its geographical distribution and treatment response to PEG-IFN and ribavirin [8]. Due to the low-fidelity of RNAdependent RNA polymerase, NS5A, in viral replication, there are many quasispecies within one infected individual [16]. Primarily HCV infects hepatocytes of humans and chimpanzees. Various molecules including CD81 [17], scavenger receptor class B type I [18], Claudin-1 [19], low density lipoprotein receptor [20], and glycosaminoglycan [21] have been shown to be the receptors for HCV. The recent discovered receptor, occludin, however, is the crucial factor allowing HCV replication in mice [22].

The studies on HCV evasion from host immunity and host immunity in HCV patients that have spontaneously recovered have allowed us to address important immunological parameters related to protective immunity. Spontaneous recovery has been linked to multifunctional $\mathrm{CD}^{+} \mathrm{T}$ cells, cross-genotype cytotoxic $\mathrm{CD} 8^{+} \mathrm{T}$ cells, as well as cross-genotype neutralizing antibodies. These studies have advanced our understanding on protective immunity against $\mathrm{HCV}$ and provide a blueprint for $\mathrm{HCV}$ vaccine developments. There were many vaccines developed and tested in preclinical setting in the past. Among them, several vaccines have now advanced to clinical trials. Herein, we would examine the immune evasion strategies used by HCV, discuss correlates of successful host immunity against HCV infection, and review some prospective therapeutic vaccines to chronic HCV infection.

\section{Immune Evasion by HCV}

HCV can target many different effectors of the immune system, which enables its escape from host immune surveillance and ultimately leads to chronic infection. HCV can inhibit IFN- $\alpha$ production, inhibit NK activity, and produce escape mutants from antibody and $\mathrm{CD} 8^{+} \mathrm{T}$ cell recognition. All these have aided to the development of chronic HCV infection.

Double-stranded RNA expressed by many RNA viruses during replication could be recognized by host pathogen- recognition receptors, such as TLR3 and RNA helicases (RIG-I and MDA-5), which lead to anti-viral responses. The recognition of dsRNA by TLR3 triggers its signalling pathways. In addition to the MyD88-dependent pathway, the MyD88-independent pathway leads to phosphorylation and nuclear translocation of IFN regulatory factor 3 (IRF3 ) through adaptor protein TRIF [23-25]. The activation of transcription factor IRF-3 subsequently induces type 1 IFN production and other genes involved in host defence [26]. By comparison, RIG-I activates IRF-3 for type I IFN production through another pathway required a CARDcontaining adaptor protein, Cardif. During replication, HCV NS3-4A protease recognizes and cleaves both TRIF and Cardif, which blocks the signalling pathways of TLR3 and RIG-I and ultimately inhibits the production of type I IFN [27-29].

The lack of type I IFN production in patients chronically infected with HCV may indirectly lead to a decrease in NK cell activity. Activated NK cells are important effectors in innate immunity against viral infection through the secretion of inflammatory cytokines like IFN- $\gamma$ or the cytolytic ability like antibody-dependent cell-mediated cytotoxicity (ADCC) [30]. Type I IFN activates DCs which subsequently prime NK cells via the production and transpresentation of IL-15 $[31,32]$. Thus, the lack of type I IFN production might have led to the lack of IL-15 production present in the serum, which eventually causes the decrease in total number of NK cells, especially cytotoxic $\mathrm{CD} 16^{+} \mathrm{CD} 56^{\mathrm{dim}} \mathrm{NK}$ cells, in chronic HCV- infected patients [33, 34].

Antibody responses may not be sufficient to protect individuals from $\mathrm{HCV}$ infection since neutralizing antibodies are rarely found in acute HCV patients but are found in the majority of chronically infected patients at relatively high titers $(>320)[35,36]$. The failure of neutralizing antibodies in controlling HCV infection could be caused by several different factors. HCV can bind to very low-density lipoprotein (VLDL), which facilitates the uptake of HCV by hepatocytes via the interaction between ApoB and scavenger receptor class B type I, helping HCV avoid recognition by neutralizing antibodies [37]. E2 is highly glycosylated with $11 \mathrm{~N}$-linked glycans located at the conserved region outside hypervariable region 1 (HVR1), which is targeted by most antibodies. These glycosylation sites are conserved across all HCV genotypes and subtypes. Three glycans located at the CD81-binding site of E2 decrease its immunogenicity and eventually protect viruses from antibody neutralization [38]. HCV can also infect surrounding cells through a direct cellcell contact mediated by CD81 and Claudin-1, which can also avoid itself from the clearance of neutralizing antibodies [39]. Moreover, HCV can evolve into many quasispecies representing closely related but heterogenous RNA sequences within one individual during the course of infection. The number of quasispecies identified within a single sample ranges between 3-10 variants and the sequence variation occurs mainly in the HVR1 [40-42]. Studies following the evolution of HCV in one single patient well illustrated the development of quasispecies in chronic patients. Neutralizing antibodies to broad genotypes of HCV caused by continuous mounting immune response to evolving $\mathrm{HCV}$ 
could be detected in this patient. However, these antibodies could not neutralize the dominant HCV isolate from this patient at the time of sample collection. Therefore, the antibody response failed to resolve HCV infection [41]. Furthermore, the presence of interference antibodies could diminish the function of true neutralizing antibodies. Two important epitopes located at E2 envelope glycoprotein have been identified (Table 2). Whereas epitope I located at residue $412-426$ is an important neutralizing site and conserved between different genotypes, epitope II at 434-446 varies among different genotypes and generates antibodies interfering with the antibody to epitope I. When analysing the appearance of antibodies specific to these two epitopes, chronic HCV patients developed antibodies to nonprotective epitope II first. The appearance of antibodies to protective epitope I only appeared at very late time point together with equal abundant interference antibodies. Indeed, when antibodies specific to epitope II were depleted from patient plasma, this plasma, which contained antibodies to epitope I, could now provide better neutralizing capacity to a variety of genotypes [43]. In addition to the constant mutation occurred in $\mathrm{HCV}$, the induction of interfering antibodies is yet another strategy of HCV to escape from immune response. Since these interference antibodies appear earlier than the protective antibodies, a vaccine effective in generating antibodies to epitope I would be critical against HCV infection.

The emergence of escape mutations in $\mathrm{CD}^{+} \mathrm{T}$ cell epitopes requires a balance between virus infectivity and host immune response. The low-fidelity of RNA-dependent RNA polymerase, NS5A, is generally known to be the reason for the emerging of many quasispecies within HCV- infected individuals [16]. The rapid accumulation of mutated variants could be tracked back to the slow immune response generated against $\mathrm{HCV}$, which has allowed many mutations to accumulate in vivo $[40,44]$. The emerging of mutational variants in $\mathrm{CD}^{+} \mathrm{T}$ cell epitopes has been carefully described both in chimpanzees [44, 45] and in humans [46-48]. Firstly, when the mutation rate was analysed, amino acid substitutions within $\mathrm{CD}^{+} \mathrm{T}$ cell epitopes occurred more frequently compared to other regions [47]. Secondly, the lack of $\mathrm{CD} 4^{+} \mathrm{T}$ cell help in chronic phase has prevented the effectiveness of $\mathrm{CD}^{+} \mathrm{T}$ cells to clear the virus [49]. When chimpanzees with resolving HCV infection were rechallenged after $\mathrm{CD}^{+} \mathrm{T}$ cell depletion, they developed chronic $\mathrm{HCV}$ infection. The inability of $\mathrm{HCV}-$ specific $\mathrm{CD}^{+} \mathrm{T}$ cells to control HCV viremia correlated with the emerging of mutations in $\mathrm{CD}^{+} \mathrm{T}$ cell epitopes. Therefore, these ineffective $\mathrm{CD}^{+} \mathrm{T}$ cells have provided the selective pressure on shaping mutational variants of HCV. Recently, studies analysing different $\mathrm{HCV}$ variants within one chronically infected individual have shown that some HCV variants were actually emerging early during acute infection. Despite poor viral production while infecting hepatocytes, these variants survived due to poor recognition by host $\mathrm{CD}^{+} \mathrm{T}$ cells [50]. Therefore, a fine balance between virus infectivity and host immune response could shape $\mathrm{HCV}$ mutants present in chronically infected individuals.

\section{Protective Immunity to $\mathrm{HCV}$}

Despite the ineffectiveness of the host immune system to eradicate $\mathrm{HCV}$, studies on patients that have spontaneously recovered from HCV infection and vaccinated chimpanzees that have recovered from HCV challenge have allowed us to address the important immunological correlates related to HCV clearance. Some reports have shown that the clearance of HCV could be associated with certain host genetic background including host HLA types, cytokine and chemokine expression (e.g., IL-10, IL-28B, and CCR5) [5156]. For example, HCV clearance is often linked to patients with HLA-B27 allele in their MHC class I locus $[55,57]$. Since MHC class I is directly associated with antigen presentation to $\mathrm{CD}^{+} \mathrm{T}$ cells, this implies the importance of cytotoxic $\mathrm{T}$ cells in HCV eradication. Many studies published recently have provided critical immune parameters on protective immunity against $\mathrm{HCV}$.

$\mathrm{CD}^{+} \mathrm{T}$ cells are the most important effectors in controlling HCV infection. It was first recognized in earlier studies analysing acute HCV infection in chimpanzees. Few chimpanzees have resolved HCV spontaneously while most of them became chronically infected. When comparing these two groups of chimpanzees for the development of neutralizing antibodies and cytotoxic $\mathrm{CD}^{+} \mathrm{T}$ cells, spontaneously recovered chimpanzees exhibited a strong $\mathrm{CD} 8^{+} \mathrm{T}$ cell response toward multiple viral epitopes and across multiple MHC class I restrictions (Table 2) [58]. When these spontaneously recovered chimpanzees were challenged with HCV for the second time, they recovered more rapidly, within 14 days compared to 40 days in primary infection. Specific $\mathrm{CD}^{+} \mathrm{T}$ cell number inversely correlated with $\mathrm{HCV}$ viral load in the blood. Additionally when $\mathrm{CD}^{+} \mathrm{T}$ cells were depleted before the third challenge, a prolonged $\mathrm{HCV}$ infection was observed [59]. This was further supported by similar findings in human studies. When patients with chronic HCV infection were investigated, a general lack of broad specificity and cytotoxicity in $\mathrm{CD}^{+} \mathrm{T}$ cells toward HCV epitopes was observed (Table 2) [60]. A more detailed study on HLA-matched individuals with chronic infection or spontaneously resolving infection was set to investigate the breadth, magnitude, phenotype, and function of HCVspecific $\mathrm{CD} 8^{+} \mathrm{T}$ cells. Individuals with resolved $\mathrm{HCV}$ infection contained stronger $\mathrm{CD}^{+} \mathrm{T}$ cell responses $(17 / 20$ versus $9 / 20 ; P=.019)$ and specific $\mathrm{CD} 8^{+} \mathrm{T}$ cells to broader range of epitopes (Table 2; mean 2.3 versus $1 ; P=.039$ ) with higher frequency in circulation (mean 584 versus 95 per 1 million PBMC; $P=.027$ ) measured by IFN- $\gamma$ secretion in response to HCV peptides [61]. These specific $\mathrm{CD} 8^{+} \mathrm{T}$ cells proliferated vigorously in response to antigens and expressed memory CCR $7{ }^{\text {hi }} \mathrm{CD} 45 \mathrm{RA}{ }^{\text {low }} \mathrm{CD} 27^{+} \mathrm{CD} 28^{+}$phenotype $[60$, 61]. Notably a predominant expression of IL-7 receptor (CD127) on $\mathrm{HCV}$-specific $\mathrm{CD} 8^{+} \mathrm{T}$ cells was identified in patients who recovered from infection [62]. Additionally cross-genotype $\mathrm{CD} 8^{+} \mathrm{T}$ cells could limit the escape of $\mathrm{HCV}$ and help the clearance of viruses [57]. Thus, a robust multispecific and cross-genotype $\mathrm{CD}^{+} \mathrm{T}$ cell response to different epitopes implies a successful response against HCV infection. 
TABLE 2: Important epitopes of HCV recognized by T cells and B cells.

\begin{tabular}{|c|c|c|c|}
\hline Ref. & Antigen & $\begin{array}{l}\text { Epitopes } \\
\text { (aa sequence, restriction molecules) }\end{array}$ & Functional properties \\
\hline \multicolumn{4}{|l|}{ CD8 epitopes } \\
\hline \multirow{6}{*}{ Cooper et al. [58] } & E1 & $\begin{array}{l}\text { 306-315 (CSIYPGHITG, Patr-A*0402); 366-375 } \\
\text { (GNWAKVLVVL, Patr-C* 0601/C* 0602) }\end{array}$ & \multirow{6}{*}{$\begin{array}{l}\text { cytotoxic epitopes identified in recovered } \\
\text { champanzees }\end{array}$} \\
\hline & E2 & $\begin{array}{l}\text { 621-629 (TINYTIFKI, Patr-B*2001); 651-665 } \\
\text { (RCDLEDRDRSELSPL, Patr-A*0601) }\end{array}$ & \\
\hline & P7 & 781-791 (KWVPGAVYTFY, Patr-A*0601) & \\
\hline & NS2 & 997-1008 (INGLPVSARRGR, Patr-A*0402) & \\
\hline & NS3 & 1629-1637 (GAVQNEITL, Patr-B*1701) & \\
\hline & NS5A & 2055-2065 (MWSGTFPINAY, Patr-A*0601) & \\
\hline Dazert et al. [57] & NS5B & 2841-2849 (ARMILMTHF, HLA-B27) & IFN- $\gamma$ secreting and protective epitope \\
\hline \multirow{7}{*}{ Lauer et al. [61] } & core & $\begin{array}{l}\text { 41-49 (GPRLGVRAT, HLA-B7); 88-96 } \\
\text { (NEGCGWMGW, HLA-B44); 111-119 } \\
\text { (DPRRRSRNL, HLA-B7) }\end{array}$ & \multirow{7}{*}{$\begin{array}{l}\text { IFN- } \gamma \text { secreting epitopes identified in recovered } \\
\text { individuals }\end{array}$} \\
\hline & E1 & $\begin{array}{l}\text { 207-214 (CPNSSIVY, HLA-B35); 322-330 } \\
\text { (MMMNWSPTT) }\end{array}$ & \\
\hline & E2 & $\begin{array}{l}\text { 541-551 (NTRPPLGNWFG, HLA-B57); 610-619 } \\
\text { (YRLWHYPCTI, HLA-Cw7) }\end{array}$ & \\
\hline & NS2 & $\begin{array}{l}\text { 831-840 (LSPYYKRYIS, HLA-A25); 941-960 } \\
\text { (LGALTGTYVYNHLTPLRDWA); 957-964 } \\
\text { (RDWAHNGL, HLA-B37) }\end{array}$ & \\
\hline & NS3 & $\begin{array}{l}\text { 1070-1089 (ATCINGVCWTVYHGAGTRTI); } \\
\text { 1073-1081 (CINGVCWTV, HLA-A2); 1175-1183 } \\
\text { HAVGLFRA, HLA-A68); 1359-1367 (HPNIEEVAL, } \\
\text { HLA-B35); 1395-1403 (HSKKKCDEL, HLA-B8); } \\
\text { 1406-1415 (KLVALGINAV, HLA-A2); 1435-1443 } \\
\text { (ATDALMTGY, HLA-A1); 1610-1627 } \\
\text { (CLIRLKPTLHGPTPLLYR) }\end{array}$ & \\
\hline & NS4 & $\begin{array}{l}\text { 1695-1702 (IPDREVLY, HLA-B35); 1745-1754 } \\
\text { (VIAPAVQTNW, HLA-A24); 1751-1770 } \\
\text { (VFTGLTHIDAHFLSQTKQSG); 1758-1766 } \\
\text { (ETFWAKHMW, HLA-A25); 1771-1790 } \\
\text { (GIQYLAGLSTLPGNPAIASL); 1801-1809 } \\
\text { (LTTSQTLLF; HLA-B57); 1966-1976 } \\
\text { (SECCTPCSGSW, HLA-B37); 1987-1995 } \\
\text { (VLDSFKTWL, HLA-A2) }\end{array}$ & \\
\hline & NS5 & $\begin{array}{l}\text { 2162-2170 (EPEPDVAVL, HLA-B35); 2225-2233 } \\
\text { (ELIEANLLW, HLA-A25); 2461-2480 } \\
\text { (TSRSACQRQKKVTFDRLQVL); 2594-2602 } \\
\text { (ALYDVVTKL, HLA-A2); 2629-2637 } \\
\text { (KSKKTPMGF, HLA-B57); 2819-2828 } \\
\text { (TARHTPVNSW, HLA-A25); 2912-2921 } \\
\text { (LGVPPLRAWR, HLA-B57) }\end{array}$ & \\
\hline \multirow{2}{*}{$\begin{array}{l}\text { Wedemeyer et al. } \\
{[60]}\end{array}$} & core & $\begin{array}{l}\text { 35-44 (YLLPRRGPRL, HLA-A2); 132-140 } \\
\text { (DLMGYIPLV, HLA-A2) }\end{array}$ & \multirow{2}{*}{$\begin{array}{l}\text { cytotoxic and IFN- } \gamma \text { secreting epitopes identified } \\
\text { in chronic \& recovered individuals }\end{array}$} \\
\hline & NS3 & $\begin{array}{l}\text { 1073-1081 (CVNGVCWTV, HLA-A2); 1406-1415 } \\
\text { (KLVALGINAV, HLA-A2) }\end{array}$ & \\
\hline Urbani et al. [62] & NS3 & $\begin{array}{l}\text { 1073-1081 (CVNGVCWTV, HLA-A2); 1406-1415 } \\
\text { (KLVALGINAV, HLA-A2) }\end{array}$ & $\begin{array}{l}\text { Differential expression of CD127 on IFN- } \gamma \\
\text { secreting CD } 8^{+} \mathrm{T} \text { cells }\end{array}$ \\
\hline \multicolumn{4}{|l|}{ CD4 epitopes } \\
\hline \multirow[t]{2}{*}{ Day et al. [67] } & NS3 & $\begin{array}{l}\text { 1248-1262 (GYKVLVLNPSVAATL, } \\
\text { HLA-DRB1*0401); 1579-1597 } \\
\text { (SGENLPYLVAYQATVCARA, HLA-DRB1*0401) }\end{array}$ & \multirow[t]{2}{*}{$\begin{array}{l}\mathrm{CCR}^{+} \mathrm{CD} 45 \mathrm{RA}^{-} \mathrm{CD} 27^{+} \text {tetramer-positive } \mathrm{T} \text { cells } \\
\text { identified in recovered individuals }\end{array}$} \\
\hline & NS4 & $\begin{array}{l}\text { 1770-1790 (SGIQYLAGLSTLPGNPAIASL, } \\
\text { HLA-DRB1*0401) }\end{array}$ & \\
\hline
\end{tabular}


Table 2: Continued.

\begin{tabular}{|c|c|c|c|}
\hline Ref. & Antigen & $\begin{array}{l}\text { Epitopes } \\
\text { (aa sequence, restriction molecules) }\end{array}$ & Functional properties \\
\hline \multicolumn{4}{|l|}{ CD4 epitopes } \\
\hline Lasarte et al. [68] & core & $\begin{array}{l}\text { 99-112 (SPRGSRPSWGPTDP, HLA-DR); 146-159 } \\
\text { (GAARALAHGVRVLE, HLA-DR) }\end{array}$ & $\begin{array}{l}\text { Epitopes recognized by IL- } 2 \text { secreting Th cells in } \\
\text { IFN- } \alpha \text { treatment responders }\end{array}$ \\
\hline \multirow{3}{*}{$\begin{array}{l}\text { Schulze zur Wiesch } \\
\text { et al. [66] }\end{array}$} & NS3 & $\begin{array}{l}\text { 1209-1219 (VFTDNSSPPVV, HLA-DRB3*0201); } \\
\text { 1251-1260 (VLVLNPSVAA, } \\
\text { HLA-DRB1*0101/0401/1104 \& DRB3*0101); } \\
\text { 1542-1550 (YMNTPGLPV; HLA-DRB1*0701); } \\
\text { 1587-1598 (VAYQATVCARAQ; HLA-DRB1*1001) }\end{array}$ & \multirow{3}{*}{$\begin{array}{l}\text { Broad specificity to NS3/4/5 proteins identified by } \\
\text { proliferation and IFN- } \gamma \text { secretion in recovered } \\
\text { individuals }\end{array}$} \\
\hline & NS4 & $\begin{array}{l}\text { 1775-1785 (LAGLSTLPGNP, } \\
\text { HLA-DRB1*0401/0404/0407/1104); 1913-1922 } \\
\text { (VQWMNRLIAF, HLA-DRB1*1104); 1915-1924 } \\
\text { (WMNRLIAFAS, HLA-DRB1*1001) }\end{array}$ & \\
\hline & NS5 & $\begin{array}{l}\text { 2273-2286 (EILRKSRRFAQALP, HLA-DRB1*1104); } \\
\text { 2423-2436 (SYSWTGALVTPCAA; } \\
\text { HLA-DRB1*0701); 2577-2588 (ARLIVFPDLGVR, } \\
\text { HLA-DRB1*0404/0407); 2944-2954 } \\
\text { (YLFNWAVRTKL, HLA-DRB1*1104) }\end{array}$ & \\
\hline \multicolumn{4}{|l|}{ Antibody epitopes } \\
\hline Law et al. [72] & E2 & 396-424/436-447/523-540 (conformational epitope) & $\begin{array}{l}\text { Conserved cross-genotype, neutralizing antibody } \\
\text { epitope }\end{array}$ \\
\hline Meunier et al. [70] & E1 & 313-327 (ITGHRMAWDMMMNWS) & $\begin{array}{l}\text { Conserved cross-genotype, neutralizing antibody } \\
\text { epitope }\end{array}$ \\
\hline Perotti et al. [71] & E2 & $412-423 / 528-535$ (conformational epitope) & $\begin{array}{l}\text { Conserved cross-genotype, neutralizing antibody } \\
\text { epitope }\end{array}$ \\
\hline \multirow[t]{2}{*}{ Zhang et al. [43] } & E2 & 412-426 (QLINTNGSWHINSTA) & $\begin{array}{l}\text { Conserved cross-genotype, neutralizing antibody } \\
\text { epitope }\end{array}$ \\
\hline & E2 & $434-446$ & Unconserved interfering antibody epitope \\
\hline
\end{tabular}

Robust $\mathrm{CD} 4^{+} \mathrm{T}$ cells with broad specificity and function predict a spontaneous recovery in individuals with acute $\mathrm{HCV}$ infection. $\mathrm{CD}^{+} T$ helper cells are important in shaping adaptive immune effectors like $\mathrm{B}$ cells and $\mathrm{CD} 8^{+} \mathrm{T}$ cells. Even with the critical role of $\mathrm{CD} 8^{+} \mathrm{T}$ cells in controlling $\mathrm{HCV}$ infection, a broad specificity of $\mathrm{CD}^{+} \mathrm{T}$ cells to $\mathrm{HCV}$ could be found in some patients with chronic HCV infection [63]. The difference between spontaneous resolving and chronic persistence seems to lie on the quality of the $\mathrm{CD} 4^{+} \mathrm{T}$ cell response [62-65]. When studying the specificity of $\mathrm{CD}^{+} \mathrm{T}$ cells in acute HCV infected individuals, individuals with spontaneously resolving $\mathrm{HCV}$ infection have $\mathrm{CD} 4^{+} \mathrm{T}$ cells specific to many different HCV epitopes compared to chronically infected individuals (Table 2) [62, 66, 67]. A similar study was reported in patients responding to IFN$\alpha$ treatment (Table 2) [68]. When the function of $\mathrm{CD}^{+} \mathrm{T}$ cells was analysed, multifunctional $\mathrm{CD} 4^{+} \mathrm{T}$ cells with the capacity to secrete IL- 2 and IFN- $\gamma$ seemed to correlate better with $\mathrm{HCV}$ clearance during acute $\mathrm{HCV}$ infection. In contrast, acute HCV- infected individuals became chronically infected when their specific $\mathrm{CD} 4^{+} \mathrm{T}$ cells secreted no IL-2 $[62,65]$. Therefore, multi-specific $\mathrm{CD} 4^{+} \mathrm{T}$ cells capable of secreting IL-2 and IFN- $\gamma$ are critical in the generation of quality $\mathrm{CD}^{+} \mathrm{T}$ cell responses necessary for HCV eradication.
In spite of the general lack of protection with neutralizing antibodies to $\mathrm{HCV}$, cross-genotype neutralizing antibodies seem to render protection against $\mathrm{HCV}$ infection. HCVinfected patients can develop anti-HCV antibodies to HCV core, NS3, NS4, and NS5 proteins as measured by a third generation of anti-HCV assays [69]. Neutralizing antibodies to $\mathrm{HCV}$, however, are detected using E1 and E2 expressing HCV pseudotype particles (HCVpp) [35]. Since E1 and E2 proteins are present on the surface of HCV virions and are critical for viral entry into hepatocytes, specific antibodies to certain E1 and E2 regions, mostly IgG isotype, have neutralizing capacity $[35,36,70]$. New findings using human monoclonal antibodies derived from HCV infected patients demonstrated that specific antibodies against certain E1 and E2 epitopes have in vitro cross-genotype neutralizing capacity to HCVpp (Table 2) [70-72]. In addition, when these cross-genotype neutralizing antibodies were given to humanized mice following intravenous HCV challenge, these antibodies could offer passive protection and prevent HCV replication in vivo [72]. Furthermore, a study on intravenous drug users with resolved $\mathrm{HCV}$ infection demonstrated the contribution of broad neutralizing antibodies in HCV clearance. When these individuals with resolving infection experienced a secondary HCV infection, the majority of 
them $(83 \%)$ would clear the virus spontaneously compared to $25 \%$ of them in primary infection. When the specificity of neutralizing antibodies was analysed, neutralizing antibodies reacting to a broad range of genotypes were found in patients spontaneously recovered instead of those who became chronically infected [73].

Studies on patients responding to IFN- $\alpha$-based therapy have revealed the importance of innate immunity in HCV clearance. Several genome-wide association studies on chronic HCV-infected patients have identified a strong genetic association of IL28B gene, which encoded for IFN$\lambda 3$, on the responsiveness to standard IFN- $\alpha$ and ribavirin therapy. Three different studies analysing patient populations at Australian [74], Japan [75], and United States $[56,76]$ have demonstrated that the polymorphism at the upstream of IL28B is associated strongly with sustained virological response. Patients with genotype expressing more IL28 mRNA respond better to standard IFN therapy. This genetic variation of IL28B has also been shown to be associated with individuals who were infected by $\mathrm{HCV}$ and experienced spontaneously viral clearance [56]. When different geographic populations are compared, C allele (rs 12979860 ) occurs most often in individuals from Asia, then Europe, and least common from Africa origin. Since 36.4\% of non-Africa individuals and only $9.3 \%$ of Africa individuals spontaneously clear $\mathrm{HCV}$, it further confirms the association of $\mathrm{C}$ allele to $\mathrm{HCV}$ clearance [76]. IFN- $\lambda 3$ together with IFN- $\lambda 1$ (IL-29) and IFN- $\lambda 2$ (IL-28B), which act through the receptor complex consisting of IL-28R $\alpha$ and IL-10R $\beta$ and then signal through JAK/STAT pathway, has very similar anti-viral effects as type I interferon (IFN- $\alpha$ and IFN- $\beta$ ). Although the importance of IFN- $\lambda 3$ on the immune system to combat HCV infection remains mostly unknown, IFN$\lambda$ can inhibit HCV replication in hepatoma cells (Huh-7.5) [77]. In addition, IFN- $\lambda$ can enhance antiviral activities of IFN- $\alpha$ and vice versa, which suggest the possible mechanism of IL-28B polymorphism in the responsiveness of PEG-IFN and ribavirin therapy $[77,78]$. A pilot study on chronic HCV patients received pegylated IFN- $\lambda$ alone or with ribavirin has showed some promising results in HCV RNA reduction after 4 weekly subcutaneous injections [79]. Overall, these data suggest the benefit of IFN- $\lambda$ in controlling HCV infection.

\section{Vaccine Approach}

The development of vaccines against HCV has been hampered greatly by the availability of research tools. Due to the limited tissue tropism and host selection, HCV could be generated in vitro in tissue culture system only very recently. Without tissue culture techniques, there would not have been enough viruses for vaccine antigens and immunological bioassay. The development of $\mathrm{HCV}$ pseudotype particles by genetically expressing $E 1 \& E 2$ in retrovirus vector [80] has successfully filled the gap before the discovery of cell culture HCV (HCVcc) [17]. Moreover, it facilitates the identification of various receptors for HCV entry. Currently, various vaccines are primarily tested in chimpanzees and humans. Through the identification of different receptors for HCV entry, it allows the construction of a humanized mouse model, which expresses $\mathrm{HCV}$ entry receptors like occludin [22]. Although it is still early in the development, the availability of small animal models could accelerate the preclinical screening for potential vaccine candidates.

After the diagnostic kits for HCV became available, the implementation of HCV screening during blood transfusions and organ transplants has dramatically decreased the numbers of new cases of $\mathrm{HCV}$ infection. However, chronic HCV infection still presents in many individuals. This emphasizes the importance of therapeutic vaccination against HCV infection. One of the challenges dealing with chronic infection is to rescue impaired $\mathrm{T}$ cells. Thus, the goals of therapeutic vaccines are to generate broad and multispecific $\mathrm{CD}^{+} T$ cells, to activate cytotoxic $\mathrm{CD} 8^{+} T$ cells and finally to generate cross-genotype neutralizing antibodies. Due to the variability of HCV, a combination approach including vaccination, anti-viral therapy or immune modulation might be necessary. Many vaccines have been tested by both nonprofit and profit organizations. Most of them are still at preclinical stage with some advanced into phase I or II trials to determine safety and efficacy of the candidate vaccines in a small group of patients. Earlier vaccine approaches aiming to generate neutralizing antibodies against E1 failed to show efficacy in chronic HCV patients in spite of its effect on antibody production. Consequently, the recombinant E1 with alum adjuvanted vaccine has been discontinued after an unsatisfactory outcome in its phase II trial [88]. Therefore, most of $\mathrm{HCV}$ vaccines are focused on generating cytotoxic $\mathrm{CD}^{+} T$ cells in addition to antibody responses. Different vaccines have been developed over years including epitope vaccines, vector vaccines, recombinant protein vaccines, and DNA vaccines. A review on the progress and efficacy of vaccines currently in clinical trials is summarized in Table 3.

4.1. Epitope Vaccines. HCV peptide-based vaccines with different adjuvants are among the earliest vaccines aiming to induce $\mathrm{Th} 1$ and cytotoxic $\mathrm{T}$ cell response in chronic HCV patients. One of these, IC41, contains 5 conservative peptides from core, NS3 and NS4 proteins, which are conserved within HCV genotype 1 and 2, and include 4 known HLA-A2 epitopes and 3 promiscuous CD4 $4^{+}$epitopes. In a randomized, dose escalating phase I trial, 128 HLA$\mathrm{A} 2^{+}$healthy volunteers received 4 subcutaneous vaccinations every 4 weeks. IC41 adjuvanted with poly-L-arginine was well tolerated by these healthy volunteers [89]. When this vaccine was given to 60 chronic HCV nonresponders, there were $67 \%$ of patients with specific $\mathrm{T}$ cell proliferation, $33 \%$ with specific IFN- $\gamma$-secreting $\mathrm{CD}^{+} \mathrm{T}$ cells, and $25 \%$ with specific IFN- $\gamma$-secreting $\mathrm{CD}^{+} \mathrm{T}$ cells. Three responders with the strongest IFN- $\gamma$-secreting $\mathrm{T}$ cells had a transient decline in serum HCV RNA ( $>1 \log$ ) [81]. Since the response was not efficient in controlling $\mathrm{HCV}$ viral load, IC41 would require further modifications by using more intense regimens and stronger adjuvants or could be incorporated into the combination therapy with PEG-IFN and ribavirin [90]. Other two peptide vaccines composed of peptides derived from conservative region of HCV with ISA51, an 
TABLE 3: Main vaccines in clinical trials for HCV.

\begin{tabular}{|c|c|c|c|c|}
\hline Vaccine & Subject & Stage & Outcome & Ref. \\
\hline $\begin{array}{l}\text { Peptides (core, NS3, } \\
\text { NS4)/poly-L-arginine } \\
\text { (IC41) }\end{array}$ & $\begin{array}{l}60 \mathrm{HLA}^{-\mathrm{A} 2} 2^{+} \text {chronic } \\
\mathrm{HCV} \text { nonresponders }\end{array}$ & II & $\begin{array}{l}67 \% \text { responding to peptide plus adjuvant } \\
\text { treatment versus } 17 \% \text { to peptide alone; } 3 \text { patients } \\
\text { with transient decline of serum HCV RNA } \\
(>1 \log )\end{array}$ & {$[81]$} \\
\hline $\begin{array}{l}\text { Peptide (core)/ } \\
\text { emulsified with ISA51 }\end{array}$ & $\begin{array}{l}26 \text { chronic } \mathrm{HCV} \\
\text { patients }\end{array}$ & I & $\begin{array}{l}\text { Well tolerated with no severe toxicity; } 15 / 25 \\
\text { responder; } 2 / 25 \text { with } 1 \text { log decline on HCV RNA }\end{array}$ & {$[82]$} \\
\hline $\begin{array}{l}\text { Peptides } \\
\text { (NS3)/Virosome }\end{array}$ & 30 healthy volunteers & I & No result released & $\begin{array}{l}\text { NCT004 } \\
45419\end{array}$ \\
\hline $\begin{array}{l}\text { MVA-HCV } \\
\text { NS3/NS4/NS5B } \\
(\text { TG4040) }\end{array}$ & $\begin{array}{l}15 \text { chronic } \mathrm{HCV} \\
\text { patients }\end{array}$ & I & $\begin{array}{l}\text { Well tolerated; } 6 / 15 \text { with decline on HCV RNA } \\
(0.5-1.4 \log )\end{array}$ & {$[83]$} \\
\hline $\begin{array}{l}\text { HCV gpE1/E2 } \\
\text { glycoproteins/MF59 }\end{array}$ & 60 healthy volunteers & I & No result released & $\begin{array}{l}\text { NCT005 } \\
00747\end{array}$ \\
\hline $\begin{array}{l}\text { Recombinant yeast } \\
\text { transfect with HCV } \\
\text { NS3-core fusion } \\
\text { protein (GI5005) }\end{array}$ & $\begin{array}{l}\text { Chronic HCV } \\
\text { patients }\end{array}$ & II & $\begin{array}{l}\text { Well tolerate and showed better virology response } \\
\text { in chronic patients after triple therapy }\end{array}$ & {$[84]$} \\
\hline $\begin{array}{l}\text { HCV core protein/ } \\
\text { ISCOMATRIX }\end{array}$ & 30 healthy volunteers & I & $\begin{array}{l}\text { Well tolerated with mild local redness; all } \\
\text { developed antibody response, } 7 / 8 \text { showed } \\
\text { cytokine production \& } 2 / 8 \text { showed cytotoxic } \mathrm{T} \\
\text { cell response in the group with highest antigen } \\
\text { dose }(50 \mu \mathrm{g})\end{array}$ & {$[85]$} \\
\hline $\begin{array}{l}\text { NS3/4A DNA vaccine } \\
\text { (ChronVac-C) }\end{array}$ & $\begin{array}{l}12 \text { chronic } \mathrm{HCV} \\
\text { patients }\end{array}$ & $\mathrm{I} / \mathrm{II} \mathrm{a}$ & $\begin{array}{l}\text { Safe, immunogenic with transient effect on serum } \\
\text { viral load }\end{array}$ & {$[86]$} \\
\hline $\begin{array}{l}\text { Recombinant core } \\
\text { protein \& core/E1/E2 } \\
\text { DNA vaccine } \\
(\mathrm{CIGB}-230)\end{array}$ & $\begin{array}{l}15 \text { chronic } \mathrm{HCV} \\
\text { patients }\end{array}$ & I & $\begin{array}{l}\text { Safe, immunogenic, and stabilized liver function } \\
\text { with persistence detection of HCV RNA }\end{array}$ & {$[87]$} \\
\hline
\end{tabular}

emulsified incomplete Freud adjuvant, were shown to be safe in HCV-infected patients [82, 91]. Preliminarily, 26 patients received subcutaneous injection of a conserved peptide derived from HCV core (C35-44, YLLPRRGPRL) biweekly. 15 of 25 patients showed an increase in peptidespecific $\mathrm{CD} 8^{+} \mathrm{T}$ cell response measured by IFN $-\gamma$ production and 2 patients demonstrated $1 \log$ decrease in $\mathrm{HCV}$ viral load after 12 vaccinations. The clinical efficacy would require further validation in phase II trial [82]. In addition, another phase I trial with virosome-based vaccine containing NS3 peptides derived from HCV is ongoing. It is a singleblinded placebo-controlled randomised trial with 30 healthy volunteers to evaluate dose-dependent safety and vaccineinduced immune response (ClinicalTrials.gov Identifier: NCT00445419). No data from this clinical study have been released at this time. Overall, the response with peptidebased vaccines shows good tolerability but their efficacy remains to be optimised.

4.2. Vector Vaccines. HCV vaccines delivered by attenuated virus vectors could induce effective $\mathrm{CD} 4^{+}$and $\mathrm{CD}^{+} T$ cell responses. Modified Virus of Ankara (MVA), a highly attenuated poxvirus strain, is immunogenic and safe compared to other strains of poxvirus due to the lack of several genes coding for immunomodulatory proteins, such as the soluble receptors for IFN- $\gamma$, type I IFN, TNF- $\alpha$, and CCchemokines [92]. It has been used in several different vaccine designs, such as HIV, tuberculosis, colorectal cancer, and melanoma [93-96]. Owing to its high immunogenicity and cross-reactivity, individuals immunized with vaccinia virus or MVA-based vaccines have a strong antivector response. However, this preexisting immunity would not affect the induction of immunity against vectored antigens despite lower amount of specific T cells and antibodies to vectored antigens were observed [97]. Vaccines based on MVA vector expressing HCV antigens including NS3, NS4, and NS5B have been shown to induce IFN- $\gamma$-secreting $\mathrm{CD} 4^{+} \mathrm{T}$ cells and specific $\mathrm{CD} 8^{+} \mathrm{T}$ cells capable of secreting IFN $-\gamma$ and killing in vitro and in vivo when tested in HLA-A2.1 and HLAB7.2 transgenic mice [98]. The phase I trial in 15 chronic $\mathrm{HCV}$ patients who received 3 weekly injections demonstrated that MVA-HCV (TG4040) was well tolerated, and 6 of 15 patients showed a decline in HCV viral load $(0.5-1.4 \log )$ associated with significant increase in IFN- $\gamma$-secreting $\mathrm{T}$ cells [83]. Currently, a phase II trial has been proposed to treat chronic HCV patients in combinational therapy with PEGIFN and ribavirin.

4.3. Recombinant Protein Vaccines. Recombinant HCV proteins require a strong Th1 adjuvant in order to generate specific T cell response to HCV. HCV E1/E2 glycoproteins emulsified with MF59, a proprietary oil-in-water emulsion adjuvant, have shown to induce a strong $\mathrm{CD}^{+} T$ cell response with significant production of neutralizing antibodies to $\mathrm{E} 1$ 
and E2 in nonhuman primates [99]. No information has been released from one double-blinded placebo-controlled randomized trial with 60 healthy volunteers to evaluate dosedependent safety and vaccine-induced immune response (ClinicalTrials.gov Identifier: NCT00500747). The vaccine, GI-5005, designed to treat chronic HCV infection is containing heat-killed yeast cells expressing conserved NS3core fusion protein. Because of its yeast components, this vaccine can induce robust $\mathrm{CD} 4^{+}$and cytotoxic $\mathrm{CD} 8^{+} \mathrm{T}$ cell responses. In preclinical studies, vaccinated mice exhibited strong Th1 with IL-2 and IFN- $\gamma$ production and cytotoxic activity to NS3 and core proteins measured by in vitro killing assay and in vivo tumor challenge experiment. Biweekly repeated administration could effectively improve their specific immune response [100]. With this successful pre-clinical result, phase I trial has also demonstrated its safety and shown to induce immune response in chronic HCV patients [101]. Phase II trial was designed to compare a combined therapy with GI-5005 and PEG-IFN/ribavirin to PEG-IFN/ribavirin alone in chronic HCV patients. At the end of 48-week treatment, patients received GI-5005 and PEG-IFN/ribavirin had $74 \%$ of response rate determined by HCV RNA less than $25 \mathrm{IU} / \mathrm{mL}$ in contrast to $59 \%$ without GI-5005. In addition, clinical tests have suggested a better liver function by ALT normalization after the combined therapy [84]. Another vaccine based on conserved HCV core protein is adjuvanted with ISCOMATRIX, an adjuvant composed of saponin, cholesterol, and phospholipid to form sphere particles with $40 \mu \mathrm{m}$ in diameter. The first phase I trial in 30 healthy volunteers provided the evidence for its safety and tolerability. As to the efficacy measured by immune response, 8 volunteers who received the highest antigen dose, $50 \mu \mathrm{g}$, all showed antibody response to core protein, 7 with cytokine-producing $\mathrm{T}$ cells, and 2 with $\mathrm{CD}^{+} \mathrm{T}$ cell responses measurable by intracellular IFN- $\gamma$ staining [85]. A phase Ib trial is prepared to evaluate its safety and immune response in chronic $\mathrm{HCV}$ - infected patients.

4.4. DNA Vaccines. DNA vaccines using naked DNA delivered by electroporation have been designed to treat chronic HCV patients. Due to the heterogeneity of HCV subtypes in most chronically infected patients, a DNA vaccine was designed to include the most conserved region including NS3 and NS4A. Through extensive codon modification, the DNA can be effectively expressed in vivo and elicit a Th1 response and cytotoxic response. These primed $\mathrm{CD} 8^{+} T$ cells could effectively eliminate NS3/4A expressing hepatocytes and tumor cells in mouse model $[102,103]$. This DNA vaccine (ChronVac-c) has been given to 12 patients with chronic HCV infection through intramuscular electroporation. Preliminary results suggested that the vaccine is safe and immunogenic after 4 monthly vaccinations. Two out of three patients received the highest dose of $1500 \mu \mathrm{g}$ showed a decrease in serum HCV RNA $(1.2 \& 2.4 \mathrm{log})$. Moreover, after completing the vaccination, three patients who received standard IFN- $\alpha$-based therapy had an accelerated clearance in $\mathrm{HCV}$ viral load. Therefore, ChronVac-c has been proposed to treat chronic HCV patients in combination with standard IFN- $\alpha$-based therapy [86]. Another DNA vaccine currently in phase I clinical trial is CIGB-230, a mixture of recombinant HCV core protein and core/E1/E2-expressing plasmid DNA. Vaccination in 15 chronic HCV patients showed that this vaccine is safe, partially immunogenic, and able to stabilize liver histology despite persistent detection of $\mathrm{HCV}$ RNA [87].

The lessons from studying protective immunity against acute HCV infection have taught us the importance of multifunctional $\mathrm{CD}^{+} \mathrm{T}$ cells toward a broad spectrum of viral epitopes. With the help of these $\mathrm{CD} 4^{+} \mathrm{T}$ cells, the body can then generate functional cytotoxic $\mathrm{T}$ cells to eliminate virusinfected hepatocytes and produce neutralizing antibodies to prevent HCV from entering into uninfected cells [6264]. The prototype of ideal vaccine would have to meet these requirements. HCV E1/E2 glycoprotein emulsified with MF59 can induce a strong $\mathrm{CD} 4^{+} \mathrm{T}$ cell response and neutralizing antibody to E1 and E2 [99]. Vaccination with defective alphaviral particles with RNA encoding for HIV gag has shown to generate a strong gag-specific $\mathrm{CD}^{+} \mathrm{T}$ cell response [104]. Through different adjuvant and antigen combinations, Lin et al. [105] have formulated a prime-boost regimen. Mice were first primed with E1/E2 glycoprotein, $\mathrm{CpG}$, and MF59 to induce robust Th1 response, and followed by the boost vaccination with defective alphaviral particles with RNA encoding for HCV E1/E2/NS3-5 to generate a strong cytotoxic $\mathrm{CD}^{+} \mathrm{T}$ cell response. With this protocol, mice also generated neutralizing antibodies to E1/E2 capable of neutralizing heterogeneous HCV isolates. Although this vaccine approach remains to be evaluated in other preclinical trials, this would set a prototype for the next generation of $\mathrm{HCV}$ vaccines.

\section{Conclusion}

Various immunological parameters favoring HCV clearance have gradually been identified. Together with the knowledge on the strategies deployed by HCV, we now have a good picture on the war against chronic HCV infection. The issue would lie on how to use the information in various vaccine platforms the scientists worldwide have built for years. In addition to vaccine development, efforts on developing anti-viral drugs are underway. Several targets for drug development have been proposed including NS34A serine protease, NS5B RdRp, HCV 5'-NCR, HCV viral entry and fusion, and p7 ion channel. Among them, NS3$4 \mathrm{~A}$ serine protease inhibitor has gone into clinical trial with edges on blocking viral replication and enhancing viral recognition by innate immunity. Since the nature of $\mathrm{HCV}$ in chronic infected patients is changeable, we would have to modify our strategy accordingly. A combination therapy including vaccination, anti-viral therapy like NS3$4 \mathrm{~A}$ protease inhibitor, and immune modulation like IFN$\alpha$ or IFN- $\lambda$ would need to be tailored to meet individual requirements. With the help of NS3-4A protease inhibitor, antigen-presenting cells, especially DCs and Kupffer cells, and infected hepatocytes can now sense HCV infection by TLR3 and RIG-I pathways, which consequently activates innate and adaptive immune responses. Since the immune response to $\mathrm{HCV}$ is skewed in chronic $\mathrm{HCV}$ patients, it can be 
redirected toward Th1 and cytotoxic $\mathrm{T}$ cell responses through the work of vaccines and immune modulators. Hence, the availability of multiple vaccines and treatment options is critical in treating chronic HCV patients.

\section{References}

[1] C. W. Shepard, L. Finelli, and M. J. Alter, "Global epidemiology of hepatitis C virus infection," Lancet Infectious Diseases, vol. 5, no. 9, pp. 558-567, 2005.

[2] G.-L. Xia, C.-B. Liu, H.-L. Cao, et al., "Prevalence of hepatitis $\mathrm{B}$ and $\mathrm{C}$ virus infections in the general Chinese population. Results from a nationwide cross-sectional seroepidemiologic study of hepatitis A, B, C, D, and E virus infections in China, 1992," International Hepatology Communications, vol. 5, no. 1, pp. 62-73, 1996.

[3] C. Frank, M. K. Mohamed, G. T. Strickland, et al., "The role of parenteral antischistosomal therapy in the spread of hepatitis C virus in Egypt," Lancet, vol. 355, no. 9207, pp. 887-891, 2000.

[4] M. J. Alter, "Hepatitis C virus infection in the United States," Journal of Hepatology, vol. 31, no. 1, pp. 88-91, 1999.

[5] G. L. Armstrong, A. Wasley, E. P. Simard, G. M. McQuillan, W. L. Kuhnert, and M. J. Alter, "The prevalence of hepatitis C virus infection in the United States, 1999 through 2002," Annals of Internal Medicine, vol. 144, no. 10, pp. 705-714, 2006.

[6] M. J. Tong, N. S. El-Farra, A. R. Reikes, and R. L. Co, "Clinical outcomes after transfusion-associated hepatitis C," New England Journal of Medicine, vol. 332, no. 22, pp. 14631466, 1995.

[7] A. M. Di Bisceglie, J. Thompson, N. Smith-Wilkaitis, E. M. Brunt, and B. R. Bacon, "Combination of interferon and ribavirin in chronic hepatitis C: re-treatment of nonresponders to interferon," Hepatology, vol. 33, no. 3, pp. 704-707, 2001.

[8] M. P. Manns, H. Wedemeyer, and M. Cornberg, "Treating viral hepatitis C: efficacy, side effects, and complications," Gut, vol. 55, no. 9, pp. 1350-1359, 2006.

[9] S. D. Sullivan, D. M. Jensen, D. E. Bernstein, et al., "Cost-effectiveness of combination peginterferon $\alpha$-2a and ribavirin compared with interferon $\alpha-2 \mathrm{~b}$ and ribavirin in patients with chronic hepatitis C," American Journal of Gastroenterology, vol. 99, no. 8, pp. 1490-1496, 2004.

[10] M. P. Manns, J. G. McHutchison, S. C. Gordon, et al., "Peginterferon $\alpha$-2b plus ribavirin compared with interferon $\alpha$-2b plus ribavirin for initial treatment of chronic hepatitis C: a randomised trial," Lancet, vol. 358, no. 9286, pp. 958965, 2001.

[11] M. W. Fried, M. L. Shiffman, K. R. Reddy, et al., "Peginterferon $\alpha$-2a plus ribavirin for chronic hepatitis $\mathrm{C}$ virus infection," New England Journal of Medicine, vol. 347, no. 13, pp. 975-982, 2002.

[12] O. V. Nainan, M. J. Alter, D. Kruszon-Moran, et al., "Hepatitis C virus genotypes and viral concentrations in participants of a general population survey in the United States," Gastroenterology, vol. 131, no. 2, pp. 478-484, 2006.

[13] L. M. Blatt, M. G. Mutchnick, M. J. Tong, et al., "Assessment of hepatitis C virus RNA and genotype from 6807 patients with chronic hepatitis C in the United States," Journal of Viral Hepatitis, vol. 7, no. 3, pp. 196-202, 2000.

[14] H. Tang and H. Grise, "Cellular and molecular biology of HCV infection and hepatitis," Clinical Science, vol. 117, no. 2, pp. 49-65, 2009.
[15] P. Simmonds, J. Bukh, C. Combet, et al., "Consensus proposals for a unified system of nomenclature of hepatitis C virus genotypes," Hepatology, vol. 42, no. 4, pp. 962-973, 2005.

[16] J. Bukh, R. H. Miller, and R. H. Purcell, "Genetic heterogeneity of hepatitis C virus: quasispecies and genotypes," Seminars in Liver Disease, vol. 15, no. 1, pp. 41-63, 1995.

[17] B. D. Lindenbach, M. J. Evans, A. J. Syder, et al., "Complete replication of hepatitis C virus in cell culture," Science, vol. 309, no. 5734, pp. 623-626, 2005.

[18] E. Scarselli, H. Ansuini, R. Cerino, et al., "The human scavenger receptor class $\mathrm{B}$ type $\mathrm{I}$ is a novel candidate receptor for the hepatitis C virus," EMBO Journal, vol. 21, no. 19, pp. 5017-5025, 2002.

[19] M. J. Evans, T. von Hahn, D. M. Tscherne, et al., "Claudin-1 is a hepatitis $\mathrm{C}$ virus co-receptor required for a late step in entry," Nature, vol. 446, no. 7137, pp. 801-805, 2007.

[20] V. Agnello, G. Abel, M. Elfahal, G. B. Knight, and Q.-X. Zhang, "Hepatitis $\mathrm{C}$ virus and other flaviviridae viruses enter cells via low density lipoprotein receptor," Proceedings of the National Academy of Sciences of the United States of America, vol. 96, no. 22, pp. 12766-12771, 1999.

[21] R. Germi, J.-M. Crance, D. Garin, et al., "Cellular glycosaminoglycans and low density lipoprotein receptor are involved in hepatitis C virus adsorption," Journal of Medical Virology, vol. 68, no. 2, pp. 206-215, 2002.

[22] A. Ploss, M. J. Evans, V. A. Gaysinskaya, et al., "Human occludin is a hepatitis $\mathrm{C}$ virus entry factor required for infection of mouse cells," Nature, vol. 457, no. 7231, pp. 882886, 2009.

[23] M. Yamamoto, S. Sato, H. Hemmi, et al., "Role of adaptor TRIF in the MyD88-independent Toll-like receptor signaling pathway," Science, vol. 301, no. 5633, pp. 640-643, 2003.

[24] M. Yamamoto, S. Sato, K. Mori, et al., "Cutting edge: a novel Toll/IL-1 receptor domain-containing adapter that preferentially activates the IFN- $\beta$ promoter in the Toll-like receptor signaling," Journal of Immunology, vol. 169, no. 12, pp. 6668-6672, 2002.

[25] S. E. Doyle, S. A. Vaidya, R. O'Connell, et al., "IRF3 mediates a TLR3/TLR4-specific antiviral gene program," Immunity, vol. 17, no. 3, pp. 251-263, 2002.

[26] M. Sato, H. Suemori, N. Hata, et al., "Distinct and essential roles of transcription factors IRF-3 and IRF-7 in response to viruses for IFN- $\alpha / \beta$ gene induction," Immunity, vol. 13, no. 4, pp. 539-548, 2000.

[27] K. Li, E. Foy, J. C. Ferreon, et al., "Immune evasion by hepatitis $\mathrm{C}$ virus NS3/4A protease-mediated cleavage of the Toll-like receptor 3 adaptor protein TRIF," Proceedings of the National Academy of Sciences of the United States of America, vol. 102, no. 8, pp. 2992-2997, 2005.

[28] J. C. Ferreon, A. C. M. Ferreon, K. Li, and S. M. Lemon, "Molecular determinants of TRIF proteolysis mediated by the hepatitis C virus NS3/4A protease," Journal of Biological Chemistry, vol. 280, no. 21, pp. 20483-20492, 2005.

[29] E. Meylan, J. Curran, K. Hofmann, et al., "Cardif is an adaptor protein in the RIG-I antiviral pathway and is targeted by hepatitis C virus," Nature, vol. 437, no. 7062, pp. 11671172, 2005.

[30] L. L. Lanier, "Evolutionary struggles between NK cells and viruses," Nature Reviews Immunology, vol. 8, no. 4, pp. 259268, 2008.

[31] M. Lucas, W. Schachterle, K. Oberle, P. Aichele, and A. Diefenbach, "Dendritic cells prime natural killer cells by 
trans-presenting interleukin 15," Immunity, vol. 26, no. 4, pp. 503-517, 2007.

[32] E. F. Castillo, S. W. Stonier, L. Frasca, et al., "Dendritic cells support the in vivo development and maintenance of NK cells via IL-15 trans-presentation," Journal of Immunology, vol. 183, no. 8, pp. 4948-4956, 2009.

[33] U.-C. Meier, R. E. Owen, E. Taylor, et al., "Shared alterations in NK cell frequency, phenotype, and function in chronic human immunodeficiency virus and hepatitis $\mathrm{C}$ virus infections," Journal of Virology, vol. 79, no. 19, pp. 12365-12374, 2005.

[34] L. Golden-Mason, L. Madrigal-Estebas, E. McGrath, et al., "Altered natural killer cell subset distributions in resolved and persistent hepatitis $\mathrm{C}$ virus infection following single source exposure," Gut, vol. 57, no. 8, pp. 1121-1128, 2008.

[35] B. Bartosch, J. Bukh, J.-C. Meunier, et al., "In vitro assay for neutralizing antibody to hepatitis $\mathrm{C}$ virus: evidence for broadly conserved neutralization epitopes," Proceedings of the National Academy of Sciences of the United States of America, vol. 100, no. 24, pp. 14199-14204, 2003.

[36] C. Logvinoff, M. E. Major, D. Oldach, et al., "Neutralizing antibody response during acute and chronic hepatitis $\mathrm{C}$ virus infection," Proceedings of the National Academy of Sciences of the United States of America, vol. 101, no. 27, pp. 1014910154, 2004.

[37] P. Maillard, T. Huby, U. Andreo, M. Moreau, J. Chapman, and A. Budkowska, "The interaction of natural hepatitis $\mathrm{C}$ virus with human scavenger receptor SR-BI/Cla1 is mediated by ApoB-containing lipoproteins," FASEB Journal, vol. 20, no. 6, pp. 735-737, 2006.

[38] F. Helle, A. Goffard, V. Morel, et al., "The neutralizing activity of anti-hepatitis $\mathrm{C}$ virus antibodies is modulated by specific glycans on the E2 envelope protein," Journal of Virology, vol. 81, no. 15, pp. 8101-8111, 2007.

[39] J. M. Timpe, Z. Stamataki, A. Jennings, et al., "Hepatitis C virus cell-cell transmission in hepatoma cells in the presence of neutralizing antibodies," Hepatology, vol. 47, no. 1, pp. 1724, 2008.

[40] P. Farci, A. Shimoda, A. Coiana, et al., "The outcome of acute hepatitis $\mathrm{C}$ predicted by the evolution of the viral quasispecies," Science, vol. 288, no. 5464, pp. 339-344, 2000.

[41] T. von Hahn, J. C. Yoon, H. Alter, et al., "Hepatitis C virus continuously escapes from neutralizing antibody and T-cell responses during chronic infection in vivo," Gastroenterology, vol. 132, no. 2, pp. 667-678, 2007.

[42] P. Farci, A. Shimoda, D. Wong, et al., "Prevention of hepatitis $\mathrm{C}$ virus infection in chimpanzees by hyperimmune serum against the hypervariable region 1 of the envelope 2 protein," Proceedings of the National Academy of Sciences of the United States of America, vol. 93, no. 26, pp. 15394-15399, 1996.

[43] P. Zhang, L. Zhong, E. B. Struble, et al., "Depletion of interfering antibodies in chronic hepatitis $\mathrm{C}$ patients and vaccinated chimpanzees reveals broad cross-genotype neutralizing activity," Proceedings of the National Academy of Sciences of the United States of America, vol. 106, no. 18, pp. 7537-7541, 2009.

[44] A. L. Erickson, Y. Kimura, S. Igarashi, et al., "The outcome of hepatitis $\mathrm{C}$ virus infection is predicted by escape mutations in epitopes targeted by cytotoxic T lymphocytes," Immunity, vol. 15, no. 6, pp. 883-895, 2001.

[45] A. Weiner, A. L. Erickson, J. Kansopon, et al., "Persistent hepatitis $C$ virus infection in a chimpanzee is associated with emergence of a cytotoxic T lymphocyte escape variant,"
Proceedings of the National Academy of Sciences of the United States of America, vol. 92, no. 7, pp. 2755-2759, 1995.

[46] J. Timm, G. M. Lauer, D. G. Kavanagh, et al., "CD8 epitope escape and reversion in acute HCV infection," Journal of Experimental Medicine, vol. 200, no. 12, pp. 1593-1604, 2004.

[47] A. L. Cox, T. Mosbruger, Q. Mao, et al., "Cellular immune selection with hepatitis C virus persistence in humans," Journal of Experimental Medicine, vol. 201, no. 11, pp. 17411752, 2005.

[48] I. Tester, S. Smyk-Pearson, P. Wang, et al., "Immune evasion versus recovery after acute hepatitis $C$ virus infection from a shared source," Journal of Experimental Medicine, vol. 201, no. 11, pp. 1725-1731, 2005.

[49] A. Grakoui, N. H. Shoukry, D. J. Woollard, et al., "HCV persistence and immune evasion in the absence of memory T cell help," Science, vol. 302, no. 5645, pp. 659-662, 2003.

[50] L. Uebelhoer, J.-H. Han, B. Callendret, et al., "Stable cytotoxic $\mathrm{T}$ cell escape mutation in hepatitis $\mathrm{C}$ virus is linked to maintenance of viral fitness," PLoS Pathogens, vol. 4, no. 9, Article ID e1000143, 2008.

[51] S. Knapp, B. J. W. Hennig, A. J. Frodsham, et al., "Interleukin10 promoter polymorphisms and the outcome of hepatitis C virus infection," Immunogenetics, vol. 55, no. 6, pp. 362-369, 2003.

[52] A. Mangia, R. Santoro, M. Piattelli, et al., "IL-10 haplotypes as possible predictors of spontaneous clearance of $\mathrm{HCV}$ infection," Cytokine, vol. 25, no. 3, pp. 103-109, 2004.

[53] C. A. Goulding, A. Murphy, G. MacDonald, et al., "The CCR5- $\triangle 32$ mutation: impact on disease outcome in individuals with hepatitis $\mathrm{C}$ infection from a single source," Gut, vol. 54, no. 8, pp. 1157-1161, 2005.

[54] A. Mangia, R. Gentile, I. Cascavilla, et al., "HLA class II favors clearance of HCV infection and progression of the chronic liver damage," Journal of Hepatology, vol. 30, no. 6, pp. 984989, 1999.

[55] C. Neumann-Haefelin, S. McKiernan, S. Ward, et al., "Dominant influence of an HLA-B27 restricted CD8+ T cell response in mediating HCV clearance and evolution," Hepatology, vol. 43, no. 3, pp. 563-572, 2006.

[56] D. L. Thomas, C. L. Thio, M. P. Martin, et al., "Genetic variation in IL28B and spontaneous clearance of hepatitis C virus," Nature, vol. 461, no. 7265, pp. 798-801, 2009.

[57] E. Dazert, C. Neumann-Haefelin, S. Bressanelli, et al., "Loss of viral fitness and cross-recognition by CD8+ T cells limit HCV escape from a protective HLA-B27-restricted human immune response," Journal of Clinical Investigation, vol. 119, no. 2, pp. 376-386, 2009.

[58] S. Cooper, A. L. Erickson, E. J. Adams, et al., "Analysis of a successful immune response against hepatitis C virus," Immunity, vol. 10, no. 4, pp. 439-449, 1999.

[59] N. H. Shoukry, A. Grakoui, M. Houghton, et al., "Memory $\mathrm{CD} 8+\mathrm{T}$ cells are required for protection from persistent hepatitis C virus infection," Journal of Experimental Medicine, vol. 197, no. 12, pp. 1645-1655, 2003.

[60] H. Wedemeyer, X.-S. He, M. Nascimbeni, et al., "Impaired effector function of hepatitis C virus-specific CD8+ T cells in chronic hepatitis C virus infection," Journal of Immunology, vol. 169, no. 6, pp. 3447-3458, 2002.

[61] G. M. Lauer, E. Barnes, M. Lucas, et al., "High resolution analysis of cellular immune responses in resolved and persistent hepatitis C virus infection," Gastroenterology, vol. 127, no. 3, pp. 924-936, 2004.

[62] S. Urbani, B. Amadei, P. Fisicaro, et al., "Outcome of acute hepatitis $\mathrm{C}$ is related to virus-specific CD4 function and 
maturation of antiviral memory CD8 responses," Hepatology, vol. 44, no. 1, pp. 126-139, 2006.

[63] D. E. Kaplan, K. Sugimoto, K. Newton, et al., "Discordant role of CD4 T-cell response relative to neutralizing antibody and CD8 T-cell responses in acute hepatitis C," Gastroenterology, vol. 132, no. 2, pp. 654-666, 2007.

[64] S. Smyk-Pearson, I. A. Tester, J. Klarquist, et al., "Spontaneous recovery in acute human hepatitis $\mathrm{C}$ virus infection: functional T-cell thresholds and relative importance of CD4 help," Journal of Virology, vol. 82, no. 4, pp. 1827-1837, 2008.

[65] N. Semmo, C. L. Day, S. M. Ward, et al., "Preferential loss of IL-2-secreting CD4+ T helper cells in chronic HCV infection," Hepatology, vol. 41, no. 5, pp. 1019-1028, 2005.

[66] J. Schulze zur Wiesch, G. M. Lauer, C. L. Day, et al., "Broad repertoire of the $\mathrm{CD} 4+\mathrm{Th}$ cell response in spontaneously controlled hepatitis $\mathrm{C}$ virus infection includes dominant and highly promiscuous epitopes," Journal of Immunology, vol. 175, no. 6, pp. 3603-3613, 2005.

[67] C. L. Day, N. P. Seth, M. Lucas, et al., "Ex vivo analysis of human memory CD4 $\mathrm{T}$ cells specific for hepatitis C virus using MHC class II tetramers," Journal of Clinical Investigation, vol. 112, no. 6, pp. 831-842, 2003.

[68] J.-J. Lasarte, M. Garcia-Granero, A. Lopez, et al., "Cellular immunity to hepatitis $\mathrm{C}$ virus core protein and the response to interferon in patients with chronic hepatitis C," Hepatology, vol. 28, no. 3, pp. 815-822, 1998.

[69] J. M. Barrera, B. Francis, G. Ercilla, et al., "Improved detection of anti-HCV in post-transfusion hepatitis by a third-generation ELISA," Vox Sanguinis, vol. 68, no. 1, pp. 15-18, 1995.

[70] J.-C. Meunier, R. S. Russell, V. Goossens, et al., "Isolation and characterization of broadly neutralizing human monoclonal antibodies to the E1 glycoprotein of hepatitis C virus," Journal of Virology, vol. 82, no. 2, pp. 966-973, 2008.

[71] M. Perotti, N. Mancini, R. A. Diotti, et al., "Identification of a broadly cross-reacting and neutralizing human monoclonal antibody directed against the hepatitis C virus E2 protein," Journal of Virology, vol. 82, no. 2, pp. 1047-1052, 2008.

[72] M. Law, T. Maruyama, J. Lewis, et al., "Broadly neutralizing antibodies protect against hepatitis $\mathrm{C}$ virus quasispecies challenge," Nature Medicine, vol. 14, no. 1, pp. 25-27, 2008.

[73] W. O. Osburn, B. E. Fisher, K. A. Dowd, et al., "Spontaneous control of primary hepatitis $\mathrm{C}$ virus infection and immunity against persistent reinfection," Gastroenterology, vol. 138, no. 1, pp. 315-324, 2010.

[74] V. Suppiah, M. Moldovan, G. Ahlenstiel, et al., "IL28B is associated with response to chronic hepatitis $\mathrm{C}$ interferon$\alpha$ and ribavirin therapy," Nature Genetics, vol. 41, no. 10, pp. 1100-1104, 2009.

[75] Y. Tanaka, N. Nishida, M. Sugiyama, et al., "Genome-wide association of IL28B with response to pegylated interferon$\alpha$ and ribavirin therapy for chronic hepatitis C," Nature Genetics, vol. 41, no. 10, pp. 1105-1109, 2009.

[76] D. Ge, J. Fellay, A. J. Thompson, et al., "Genetic variation in IL28B predicts hepatitis C treatment-induced viral clearance," Nature, vol. 461, no. 7262, pp. 399-401, 2009.

[77] T. Marcello, A. Grakoui, G. Barba-Spaeth, et al., "Interferons $\alpha$ and $\lambda$ inhibit hepatitis $C$ virus replication with distinct signal transduction and gene regulation kinetics," Gastroenterology, vol. 131, no. 6, pp. 1887-1898, 2006.

[78] H. Zhu, M. Butera, D. R. Nelson, and C. Liu, "Novel type I interferon IL-28A suppresses hepatitis C viral RNA replication," Virology Journal, vol. 2, p. 80, 2005.
[79] A. J. Muir, M. Shiffman, A. Zaman, et al., "A phase 1b dose-ranging study of 4 weeks of PEG-interferon (IFN) lambda (PEG-rIL-29) in combination with ribavirin (RBV) in patients with chronic genotype 1 hepatitis $\mathrm{C}$ virus (HCV) infection," in Proceedings of the 60th Annual Meeting of the American Association for the Study of Liver Diseases, Boston, Mass, USA, October-November 2009.

[80] B. Bartosch, J. Dubuisson, and F.-L. Cosset, "Infectious hepatitis $\mathrm{C}$ virus pseudo-particles containing functional E1E2 envelope protein complexes," Journal of Experimental Medicine, vol. 197, no. 5, pp. 633-642, 2003.

[81] C. S. Klade, H. Wedemeyer, T. Berg, et al., "Therapeutic vaccination of chronic hepatitis $\mathrm{C}$ nonresponder patients with the peptide vaccine IC41," Gastroenterology, vol. 134, no. 5, pp. 1385-1395, 2008.

[82] S. Yutani, N. Komatsu, S. Shichijo, et al., "Phase I clinical study of a peptide vaccination for hepatitis $C$ virus-infected patients with different human leukocyte antigen-class I-A alleles," Cancer Science, vol. 100, no. 10, pp. 1935-1942, 2009.

[83] F. Habersetzer, J.-P. Zarski, V. Leroy, et al., "A novel vectorized HCV therapeutic vaccine (TG4040): results of a phase I study in naive patients chronically infected by HCV," in Proceedings of the 44th Annual Meeting of the European Association for the Study of the Liver (EASL '09), Copenhagen, Denmark, April 2009.

[84] J. G. McHutchison, E. J. Lawitz, T. D Boyer, et al., “GI-5005 therapeutic vaccine plus PEG-IFN/Ribavirin improves end of treatment response at 48 weeks versus PEG-IFN/Ribavirin in naive genotype 1 chronic HCV patients," in Proceedings of the 60th Annual Meeting of the American Association for the Study of Liver Disease, Boston, Mass, USA, OctoberNovember 2009.

[85] D. Drane, E. Maraskovsky, R. Gibson, et al., "Priming of CD4+ and CD8+ T cell responses using a HCV core ISCOMATRIX vaccine: a phase I study in healthy volunteers," Human Vaccines, vol. 5, no. 3, pp. 151-157, 2009.

[86] M. M. Sallberg, L. Frelin, H. Diepolder, et al., "A first clinical trial of therapeutic vaccination using naked DNA delivered by in vivo electroporation shows antiviral effects in patients with chronic hepatitis C," in Proceedings of the 44th Annual Meeting of the European Association for the Study of the Liver, Copenhagen, Denmark, April 2009.

[87] L. Alvarez-Lajonchere, N. H. Shoukry, B. Gra, et al., "Immunogenicity of CIGB-230, a therapeutic DNA vaccine preparation, in HCV-chronically infected individuals in a Phase I clinical trial," Journal of Viral Hepatitis, vol. 16, no. 3, pp. 156-167, 2009.

[88] G. Leroux-Roels, A. H. Batens, I. Desombere, et al., "Immunogenicity and tolerability of intradermal administration of an HCV E1-based vaccine candidate in healthy volunteers and patients with resolved or ongoing chronic HCV infection," Human Vaccines, vol. 1, no. 2, pp. 61-65, 2005.

[89] C. Firbas, B. Jilma, E. Tauber, et al., "Immunogenicity and safety of a novel therapeutic hepatitis $\mathrm{C}$ virus (HCV) peptide vaccine: a randomized, placebo controlled trial for dose optimization in 128 healthy subjects," Vaccine, vol. 24, no. 20, pp. 4343-4353, 2006.

[90] H. Wedemeyer, E. Schuller, V. Schlaphoff, et al., "Therapeutic vaccine IC41 as late add-on to standard treatment in patients with chronic hepatitis C," Vaccine, vol. 27, no. 37, pp. 51425151, 2009.

[91] S. Yutani, A. Yamada, K. Yoshida, et al., "Phase I clinical study of a personalized peptide vaccination for patients infected 
with hepatitis $\mathrm{C}$ virus (HCV) $1 \mathrm{~b}$ who failed to respond to interferon-based therapy," Vaccine, vol. 25, no. 42, pp. 74297435, 2007.

[92] T. J. Blanchard, A. Alcamí, P. Andrea, and G. L. Smith, "Modified vaccinia virus Ankara undergoes limited replication in human cells and lacks several immunomodulatory proteins: implications for use as a human vaccine," Journal of General Virology, vol. 79, no. 5, pp. 1159-1167, 1998.

[93] A. Dangoor, P. Lorigan, U. Keilholz, et al., "Clinical and immunological responses in metastatic melanoma patients vaccinated with a high-dose poly-epitope vaccine," Cancer Immunology, Immunotherapy, vol. 59, no. 6, pp. 863-873, 2009.

[94] E. Sandstrom, C. Nilsson, B. Hejdeman, et al., "Broad immunogenicity of a multigene, multiclade HIV-1 DNA vaccine boosted with heterologous HIV-1 recombinant modified vaccinia virus Ankara," Journal of Infectious Diseases, vol. 198, no. 10, pp. 1482-1490, 2008.

[95] T. Hawkridge, T. J. Scriba, S. Gelderbloem, et al., "Safety and immunogenicity of a new tuberculosis vaccine, MVA85A, in healthy adults in South Africa," Journal of Infectious Diseases, vol. 198, no. 4, pp. 544-552, 2008.

[96] R. Harrop, N. Connolly, I. Redchenko, et al., "Vaccination of colorectal cancer patients with modified vaccinia Ankara delivering the tumor antigen 5T4 (TroVax) induces immune responses which correlate with disease control: a phase I/II trial," Clinical Cancer Research, vol. 12, no. 11, part 1, pp. 3416-3424, 2006.

[97] L. Gudmundsdotter, C. Nilsson, A. Brave, et al., "Recombinant Modified Vaccinia Ankara (MVA) effectively boosts DNA-primed HIV-specific immune responses in humans despite pre-existing vaccinia immunity," Vaccine, vol. 27, no. 33, pp. 4468-4474, 2009.

[98] A. Fournillier, E. Gerossier, A. Evlashev, et al., "An accelerated vaccine schedule with a poly-antigenic hepatitis $C$ virus MVA-based candidate vaccine induces potent, long lasting and in vivo cross-reactive T cell responses," Vaccine, vol. 25, no. 42, pp. 7339-7353, 2007.

[99] D. T. O'Hagan, M. Singh, C. Dong, et al., "Cationic microparticles are a potent delivery system for a HCV DNA vaccine," Vaccine, vol. 23, no. 5, pp. 672-680, 2004.

[100] A. A. Haller, G. M. Lauer, T. H. King, et al., "Whole recombinant yeast-based immunotherapy induces potent T cell responses targeting HCV NS3 and Core proteins," Vaccine, vol. 25, no. 8, pp. 1452-1463, 2007.

[101] F. Habersetzer, T. F. Baumert, and F. Stoll-Keller, "GI-5005, a yeast vector vaccine expressing an NS3-core fusion protein for chronic HCV infection," Current Opinion in Molecular Therapeutics, vol. 11, no. 4, pp. 456-462, 2009.

[102] L. Frelin, G. Ahlen, M. Alheim, et al., "Codon optimization and mRNA amplification effectively enhances the immunogenecity of the hepatitis C virus nonstructural 3/4A gene," Gene Therapy, vol. 11, no. 6, pp. 522-533, 2004.

[103] G. Ahlen, J. Nystrom, I. Pult, L. Frelin, C. Hultgren, and M. Sällberg, "In vivo clearance of hepatitis $\mathrm{C}$ virus nonstructural 3/4A-expressing hepatocytes by DNA vaccine-primed cytotoxic T lymphocytes," Journal of Infectious Diseases, vol. 192, no. 12, pp. 2112-2116, 2005.

[104] S. Perri, C. E. Greer, K. Thudium, et al., "An alphavirus replicon particle chimera derived from Venezuelan equine encephalitis and Sindbis viruses is a potent gene-based vaccine delivery vector," Journal of Virology, vol. 77, no. 19, pp. 10394-10403, 2003.
[105] Y. Lin, T. Kwon, J. Polo, et al., "Induction of broad $\mathrm{CD} 4+$ and CD8+ T-cell responses and cross-neutralizing antibodies against hepatitis $\mathrm{C}$ virus by vaccination with Th1adjuvanted polypeptides followed by defective alphaviral particles expressing envelope glycoproteins gpE1 and gpE2 and nonstructural proteins 3, 4, and 5," Journal of Virology, vol. 82, no. 15, pp. 7492-7503, 2008. 


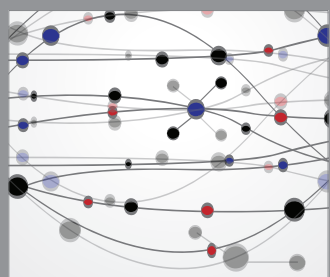

The Scientific World Journal
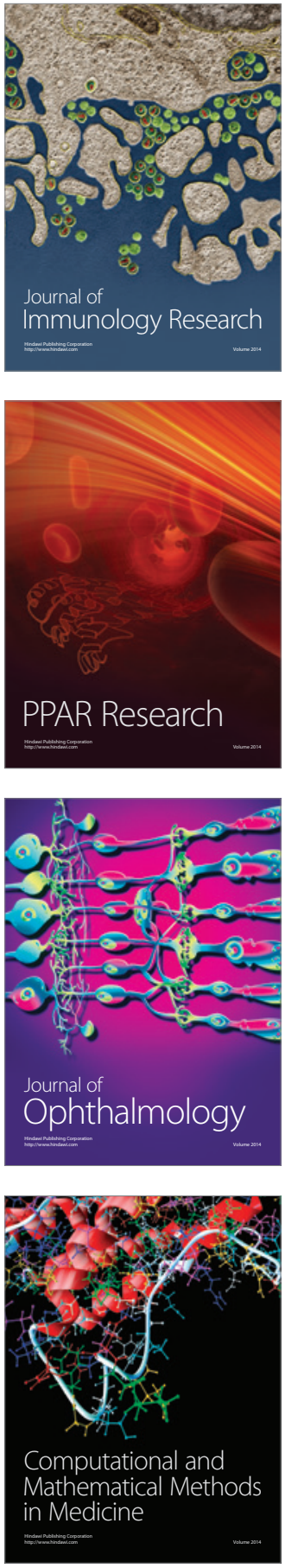

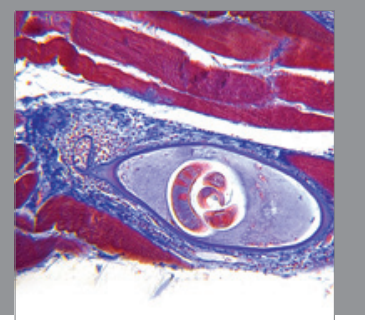

Gastroenterology

Research and Practice
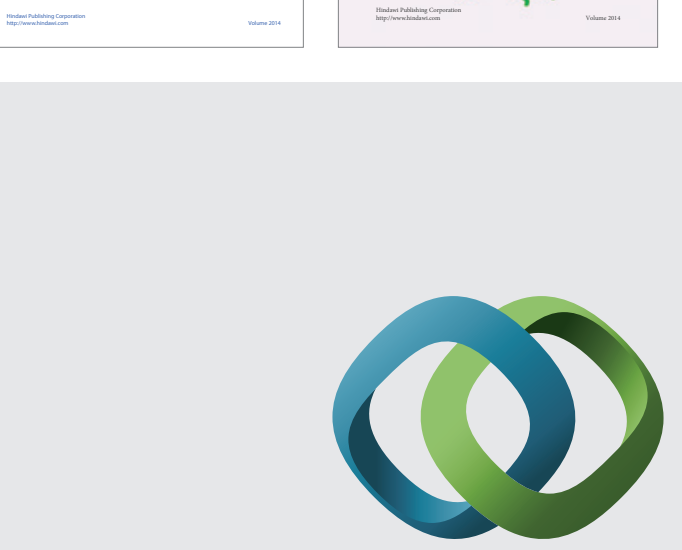

\section{Hindawi}

Submit your manuscripts at

http://www.hindawi.com
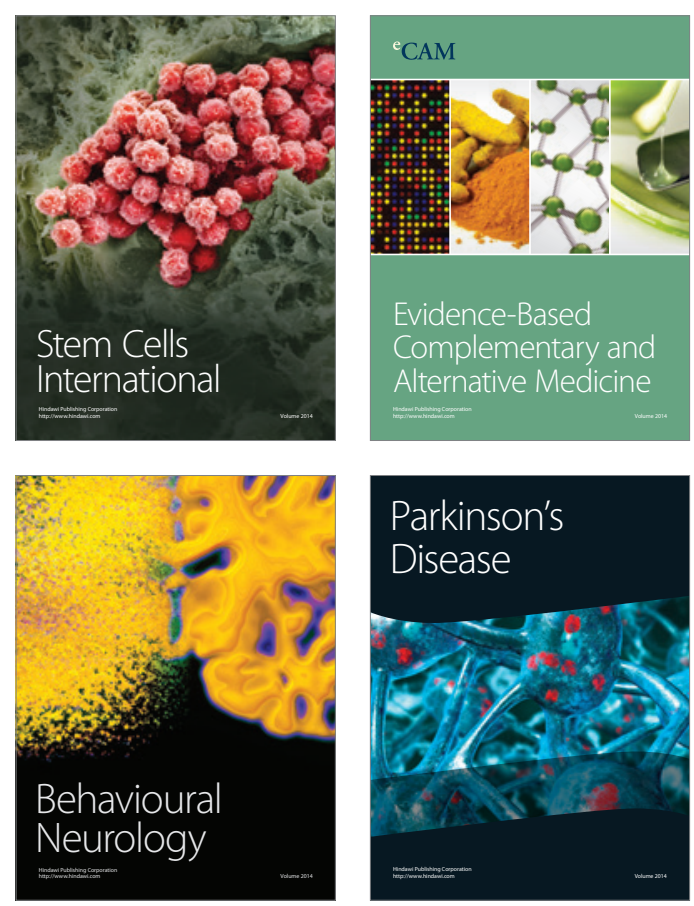

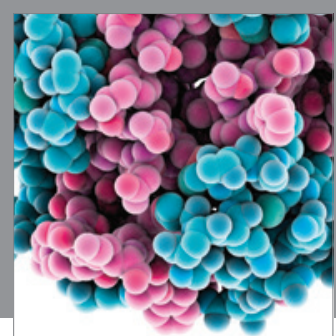

Journal of
Diabetes Research

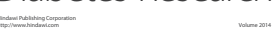

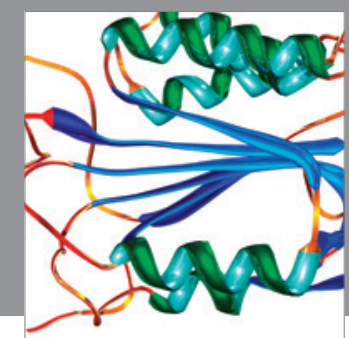

Disease Markers
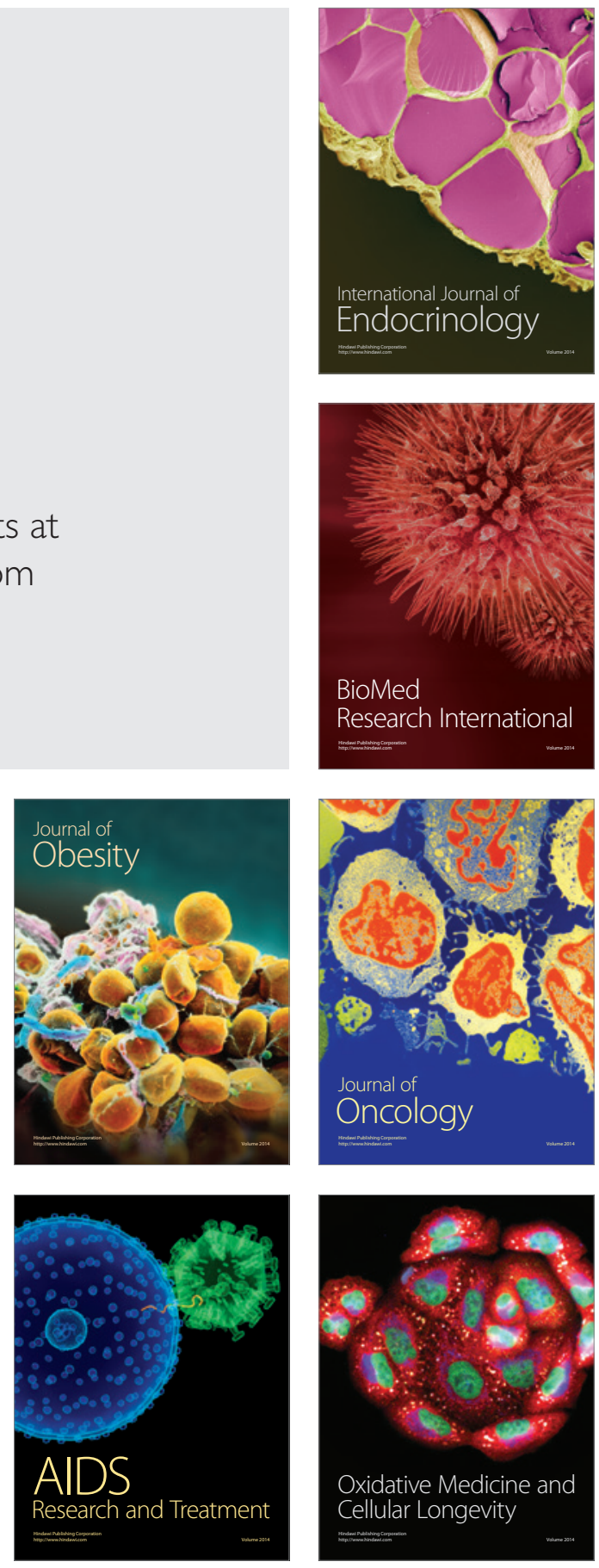